\title{
PENGEMBANGAN PENUNTUN PRAKTIKUM KIMIA DASAR II TERINTEGRASI PROBLEM BASED LEARNING (PBL) DI UNIVERSITAS MUHAMMADIYAH TAPANULI SELATAN
}

\author{
Oleh: Heni Mulyani Pohan \\ (Dosen Prodi Pendidikan Kimia, FKIP, UMTS)
}

\begin{abstract}
This study aims to: (1) analyze basic chemistry practicum II guides at UMTS, (2) develop basic PBL integrated chemistry practicum guides that are in accordance with the basic chemical syllabus II at UMTS, (3) to find out how the basic chemical practicum guide II influences integrated PBL towards students' knowledge, attitudes and skills. The sample of this study were 14 students of the fourth semester of chemistry education at Muhammadiyah University of South Tapanuli (UMTS). Before conducting research, the researcher first observes the field to analyze the UMTS II basic chemistry practicum guide. After researchers compiled a guide to basic chemistry practicum II integrated Problem Based Learning (PBL) was validated by 4 lecturers who were experts in their fields and then revised and then tested to the students. Based on the tabulation, the results of the feasibility test for integrated chemistry practicum II integrated PBL have an average of 3.88, which is feasible to use and the results of the feasibility test aspects of integrated practicum language PBL have an average of 3.75 which means it is worthy of use. The assessment results of the students' effectiveness in doing the practicum using PBL integrated II basic chemistry practicum guide that is equal to 2.05, namely the affective value of students is good and psychomotor assessment is obtained by an average of 2.36 as well as the good category. To assess the cognitive results of students the test was carried out in the form of a pretest and posttest with a pretest value of 69.29 and a posttest score of 83.57 to obtain a gain value of 0.46 , namely the effectiveness of PBL integrated II basic chemistry practicum guide.
\end{abstract}

Keywords: Basic Chemistry Practicum Guide Development, Problem Based Learning Model.

\begin{abstract}
Abstrak
Penelitian ini bertujuan untuk : (1)menganalisis penuntun praktikum kimia dasar II di UMTS, (2) mengembangkan penuntun praktikum kimia dasar II terintegrasi PBL yang sesuai dengan silabus kimia dasar II di UMTS, (3) untuk mengetahui bagaimana pengaruh penuntun praktikum kimia dasar II terintegrasi PBL terhadap pengetahuan, sikap dan keterampilan mahasiswa. Sampel penelitian ini adalah mahasiswa pendidikan kimia semester IV Universitas Muhammadiyah Tapanuli Selatan (UMTS) sebanyak 14 orang. Sebelum melakukan penelitian,
\end{abstract}


terlebih dahulu peneliti melakukan observasi ke lapangan untuk menganalisis penuntun praktikum kimia dasar II UMTS. Setelah peneliti menyusun penuntun praktikum kimia dasar II terintegrasi Problem Based Learning (PBL) divalidasi oleh 4 orang dosen yang ahli di bidangnya lalu direvisi kemudian seterusnya diuji cobakan ke mahasiswa. Berdasarkan tabulasi diperoleh hasil uji kelayakan isi penuntun praktikum kimia dasar II terintegrasi PBL memiliki rata-rata sebesar 3,88 yaitu layak digunakan dan hasil uji kelayakan aspek bahasa penuntun praktikum terintegrasi PBL memiliki rata-rata 3,75 yang artinya layak digunakan. Hasil penilaianafektif mahasiswa dalam melakukan praktikum menggunakan penuntun praktikum kimia dasar II terintegrasi PBL yaitu sebesar 2,05 yaitu nilai afektif mahasiswa sudah baik dan penilaian psikomotorik diperoleh rata-rata sebesar 2,36 juga kategori baik. Untuk menilai hasil kognitif mahasiswa dilakukan uji pemahaman tes berupa pretes dan postes dengan nilai pretes yaitu sebesar 69,29 dan nilai postes 83,57 sehingga diperoleh nilai gain sebesar 0,46 yaitu efektifitas penuntun praktikum kimia dasar II terintegrasi PBL kategori sedang.

\section{Kata kunci : Pengembangan Penuntun Praktikum Kimia Dasar II, Model Pembelajaran Berbasis Masalah.}

\section{A. Pendahuluan}

Pembelajaran kimia tidak hanya terbatas pada penggunaan atau penurunan rumus dan teori saja, melainkan merupakan produk dari sekumpulan fakta yang diperoleh dan dikembangkan berdasarkan serangkaian kegiatan (praktikum) untuk mencari jawaban atas apa, mengapa dan bagaimana (Zakiah, 2015). “ ilmu kimia tumbuh dan berkembang melalui

eksperimen...”, sehingga dalam pembelajaran kimia di sekolah perlu dilakukan pendekatan yang berbasis eksperimen (Kurniawati \& Wahyuningrum, 2011).

Mempelajari ilmu pengetahuan alam perlu adanya panduan yang berisi petunjuk praktikum, prosedur praktikum, lembar pengamatan, alat dan zat, lembar observasi kegiatan praktikum yang disebut juga penuntun praktikum. Penuntun praktikum sebagai buku ajar yang berisi pedoman untuk melakukan kegiatan praktikum di laboratorium yang bertujuan agar terciptanya kegiatan praktikum yang optimal (Tuysuz, 2010).

Observasi yang dilakukan peneliti di laboratorium kimia dasar di Universitas Muhammadiyah Tapanuli Selatan (UMTS) menunjukkan bahwa masih terdapat kekurangan penuntun praktikum kimia yang harus dikembangkan diantaranya yaitu :

1. Ada beberapa percobaan pada penuntun praktikum yang tidak sesuai dengan silabus materi kimia dasar II di UMTS.

2. Penuntun paktikum hanya berisi prosedur kerja sehingga mahasiswa hanya mengikuti apa yang diperintahkan. 
3. Mahasiswa tidak tertantang untuk bereksperimen karena penuntun tersebut tidak menarik dan monoton.

4. Penuntun praktikum tidak memiliki referensi atau daftar pustaka, sebaiknya dicantumkan.

5. Tidak terdapat pertanyaan tentang hasil percobaan yang telah dilakukan.

6. Tidak adanya aturan keselamatan dalam praktikum, hal tersebut sangat penting untuk dipahami dan dipatuhi sebelum melakukan praktikum di laboratorium karena setiap detail dari kegiatan pelaksanaan praktikum harus diteliti sedemikian rupa untuk melihat berbagai kemungkinan terdapat hal yang membahayakan.

Model pembelajaran yang tepat digunakan untuk menghasilkan pembelajaran bermakna dalam praktikum yaitu pembelajaran berbasis masalah (problem based learning) atau PBL. Esensi PBL ialah menyuguhkan berbagai situasi bermasalah yang autentik dan bermakna kepada siswa yang berfungsi sebagai batu loncatan untuk investigasi dan penyelidikan. Artinya pembelajaran berbasis masalah mengajarkan mahasiswa untuk memulai kegiatan pembelajaran dengan suatu permasalahan yang harus dipecahkan, sehingga menghasilkan pengetahuan yang baru (Desi Rosmalinda, 2013).

Penelitian ini menggunakan penelitian pengembangan Research and Development yang lebih dikenal dengan R\&D yaitu suatu proses yang dipakai untuk untuk mengembangkan dan memvalidasi suatu produk pendidikan oleh Borg \& Gall (1983) dan menggunakan model ADDIE, yang diadaptasi dari Lee \& Owens Model ini terdiri atas beberapa tahap pengembangan, yaitu Analysis (analisis), Design (desain), Development (pengembangan), Implementation (implementasi) dan Evaluation (evaluasi).

Penelitian ini menggunakan metode Problem-Based Learning (PBL) atau Pembelajaran Berbasis Masalah (PBM), karena PBL merupakan suatu pendekatan pembelajaran yang menggunakan problem/masalah sebagai sumber atau dasar pembelajaran. Dosen berperan sebagai perancang dan fasilitator. Mahasiswa aktif mengeksplorasi masalah dan bekerja sama untuk mendiskusikan serta mendapatkan jalan keluar dari masalah tersebut.

Penelitian pengembangan ini menggunakan model ADDIE, yang diadaptasi dari Lee \& Owens (Rohman, 2013). Model ini terdiri atas beberapa tahap pengembangan, yaitu Analysis (analisis), Design (desain), Development (pengembangan), Implementation (implementasi) dan Evaluation (evaluasi). Penjelasan secara singkat mengenai beberapa tahapan dalam model ADDIE adalah sebagai berikut: 
a. Tahap analisis (analysis)

Pada tahap ini ada tiga jenis kegiatan analisis yang harus dilakukan oleh peneliti, yaitu: analisis kompetensi, analisis karakteristik siswa, dan analisis instruksional.

1) Analisis kompetensi

Analisis kompetensi disebut juga analisis kurikulum.Peneliti harus cermat melakukan kegiatan analisis kurikulum, yang mencoba memahami dan mengukur tingkat kedalaman kompetensi yang dituntut oleh kurikulum.

2) Analisis karakteristik siswa

Peneliti harus mengetahui secara pasti kondisi siswa yang akan menggunakan media pembelajaran yang dikembangkan oleh peneliti. Peneliti harus mengetahui secara deta il tingkat kemampuan awal siswa, kesanggupan belajarnya, dan aspek-aspek penting lainnya.

3) Analisis instruksional

Analisis instruksional disebut juga analisis pembelajaran. Penulis harus melakukan kegiatan analisis pembelajaran dengan cermat. Hal ini dapat dilakukan dengan cara menjabarkan kompetensi umum yang ada pada kurikulum menjadi kompetensikompetensi khusus dan kemudian menentukan urutannya.

b. Tahap perancangan (design)

Pada tahap perancangan ini, ada tiga jenis kegiatan spesifik yaitu menyusun kerangka struktur (outline) dari media pembelajaran yang akan dibuat, menentukan sistematika pengembangan media pembelajaran, dan merancang alat evaluasi yang digunakan dalam media pembelajaran.

c. Tahap pengembangan (development)

Pada tahap ini media pembelajaran mulai dikembangkan sesuai dengan yang sudah ditetapkan pada tahap desain. Penerapan sistem yang akan digunakan serta memperhatikan kembali prinsip kriteria media pembelajaran yang baik perlu diperhatikan.

d. Tahap implementasi (implementation)

Media pembelajaran yang telah dibuat perlu diasosiasikan kepada siswa, jika dianggap perlu didukung dengan petunjuk penggunaan sebagai panduan awal dalam penggunaan media. 


\section{e. Tahap evaluasi (evaluation)}

Evaluasi digunakan untuk mengukur seberapa jauh siswa menguasai materi pembelajaran. Evaluasi diperoleh dalam rangka umpan balik dalam proses pembelajaran dan mengukur pencapaian melalui indikator pembelajaran.

\section{B. Metode Penelitian}

Penelitian ini berlokasi di Universitas Muhammadiyah Tapanuli Selatan Padangsidimpuan (UMTS). Penelitian dilaksanakan pada bulan Maret - Mei 2016. populasi dalam penelitian ini adalah seluruh dosen kimia dan seluruh mahasiswa jurusan kimia semester IV Universitas Muhammadiyah Tapanuli Selatan. Pengambilan sampel dalam penelitian ini dilaksanakan secara purposive sampling yaitu 2 orang dosen profesional dengan kriteria S2 dan mengajar minimal 3 tahun di UNIMED dan 2 orang dosen profesional pendidikan formal minimal S2 di UMTS mengajar minimal 3 tahun serta seluruh mahasiswa jurusan kimia semester IV di UMTS.

Prosedur dalam penelitian ini terdiri dari tahap 3 tahap yaitu : perencanaan, tahap pengembangan dan tahap evaluasi.

1. Tahap Perencanaan yaitu dilakukan analisis kebutuhan dan karakteristik mahasiswa dengan cara memberikan angket kepada dosen kimia dan mahasiswa di UMTS serta menganalisis materi yang ada di dalam silabus.

2. Tahap Pengembangan yaitu peneliti melakukan penyusunan draft (mendesain) panduan praktikum kimia dasar II terintegrasi PBL, kemudian merancang pengembangan atau mendesain produk yang akan digunakan. Desain produk ini disebut dengan prototype. Prototype ini nantinya akan dievaluasi dan direvisi supaya menghasilkan produk yang valid, praktis dan efektif.

3. Tahap Evaluasi; dilakukan uji coba prototype dan revisi berdasarkan masukan yang diperoleh.

\section{Instrumen Penelitian}

Instrumen pada penelitian ini yaitu :

a. Angket standarisasi buku penuntun praktikum dari BSNP

1. Lembar observasi

2. Test

Analisa data kevalidan menggunakan rumus: 
nilai kevalidan $=\frac{\sum \text { skorjawabanvalidator }}{\sum \text { butir }}$

\subsubsection{Lembar Penilaian Afektif}

Pada penelitian ini digunakan lembar penilaian afektif untuk menilai sikap mahasiwa yang terdiri dari berbagai aspek, yaitu mahasiswa dapat menyajikan pertanyaan/masalah, mahasiswa dapat menjawab pertanyaan dan mahasiswa dapat mengemukakan pendapat/ide.

\subsubsection{Lembar Penilaian Psikomotorik (Keterampilan)}

Pada penelitian ini digunakan lembar penilaian psikomotorik untuk menilai keterampilan mahasiwa yang terdiri dari 2 aspek, yaitu (1) menggunakan alat dan bahan percobaan, (2) merancang percobaan.

3.5.4. Tes

Tes yang dilakukan berupa tes soal. Untuk mengukur tingkat pemahaman mahasiswa tentang praktikum kimia dasar II diambil dari tes yang ada pada setiap percobaan di penuntun praktikum kimia dasar II terintegrasi PBL. Pretes diperoleh dari hasil responsi mahasiswa sebelum melakukan praktikum, dan postes diperoleh dari pertanyaan yang ada di setiap judul percobaan di penuntun praktikum.

\subsection{Uji Hipotesis}

Untuk melihat pengaruh dari penuntun praktikum kimia dasar II terintegrasi PBL dalam meningkatkan hasil belajar mahasiswa diuji dengan uji Independent Sample T-Test pada $\alpha=0,05$. Analisis data dihitung menggunakan bantuan program SPSS 21 For Windows. Efektifitas penggunaan penuntun praktikum terhadap hasil belajar digunakan rumus nilai gain.

$\mathrm{N}-$ gain $=\frac{\text { Skorpostest }- \text { skorpretest }}{\text { Skormaksimum }- \text { skorpretest }}$

Keterangan $: \mathrm{N}-$ gain $=$ Peningkatan 


\section{Hasil dan Pembahasan}

Peneliti menganalisis penuntun praktikum kimia dasar II dengan menggunakan standarisasi berdasarkan BSNP yang telah dimodifikasi yang meliputi 2 aspek yaitu : (1) kelayakan isi dan (2) kelayakan bahasa. Kemudian data akan diberikan tanda checklist $(\sqrt{ })$ pada skor 1 sampai 5 yaitu (1) sangat tidak valid, (2) tidak valid, (3) cukup valid, (4) valid, (5) sangat valid.

Berdasarkan analisis terhadap penuntun praktikum kimia dasar II dapat disimpulkan bahwa :

1. Ada beberapa percobaan yang tidak sesuai dengan silabus praktikum kimia dasar II.

2. Beberapa judul percobaan tidak dipraktikumkan oleh mahasiswa disebabkan oleh beberapa faktor antara lain yaitu zat kimia yang tersedia di laboratorium terbatas untuk melakukan percobaan tersebut, waktu untuk melakukan 10 percobaan sangat tidak memungkinkan untuk dilakukan dalam waktu 1 semester.

3. Tampilan penuntun praktikum kimia dasar II UMTS tidak menarik baik dari segi cover maupun isi karena kurang lengkap misalnya tidak ada aturan keselamatan kerja yang sangat penting untuk diperhatikan para praktikan, tidak adanya daftar pustaka, tidak ada pertanyaan untuk hasil praktikum, penyusunan draft prosedur yang monoton.

4. Tidak adanya daya tarik penuntun praktikum misalnya animasi yang kreatif atau variasi warna yang dapat memikat mata pembaca untuk membaca penuntun praktikum tersebut, hal ini sangat menunjang eksistensi dari sebuah buku pembelajaran.

Hasil uji kelayakan isi penuntun praktikum kimia dasar II terintegrasi PBL memiliki rata-rata sebesar 3,88 yaitu layak digunakan. Terdapat 19 aspek kelayakan isi yaitu (1) kejelasan identitas penuntun praktikum dengan nilai rata-rata 4 yaitu layak digunakan, (2) kemenarikan cover dengan nilai rata-rata 3,75 yaitu layak digunakan, (3) kejelasan daftar isi dengan nilai rata-rata 4,25 yaitu sangat layak digunakan, (4) kejelasan tujuan praktikum dengan nilai rata-rata 4 yaitu layak digunakan, (5) ketepatan model dengan tujuan praktikum dengan nilai rata-rata yaitu 3,25 yaitu layak digunakan, (6) kesesuaian prosedur kerja dengan nilai rata-rata 3,75 yaitu layak digunakan, (7) kesesuaian LKS dengan prosedur kerja dengan nilai rata-rata 4 yaitu layak digunakan, (8) kesesuaian laporan hasil praktikum dengan nilai rata-rata 4 yaitu layak digunakan, (9) kesesuaian penyajian tabel dengan nilai rata-rata 4,25 yaitu sangat layak digunakan, (10) 
ketepatan zat kimia yang diperlukan dengan nilai rata-rata 3,75 yaitu layak digunakan, (11) ketepatan alat-alat yang diperlukan dengan nilai rata-rata 3,75 yaitu layak digunakan, (12) menumbuhkan rasa ingin tahudengan nilai rata-rata 3,75 yaitu layak digunakan, (13) memberi tantangan untuk belajar lebih jauh dengan nilai rata-rata 4 yaitu layak digunakan, (14) kesesuaian proses penilaian kognitif dengan nilai rata-rata 4 yaitu layak digunakan, (15) kesesuaian proses afektif dengan nilai rata-rata yaitu 4 yaitu layak digunakan, (16) kesesuaian proses psikomotorik dengan nilai rata-rata 4 yaitu layak digunakan, (17) kesesuaian isi praktikum dengan silabus dengan nilai rata-rata 3,25 yaitu layak digunakan, (18) keakuratan materi kimia dasar II dengan nilai rata-rata 4 yaitu layak digunakan, (19) kesesuaian urutan praktikum dengan urutan materi kimia di silabus dengan nilai rata-rata 4 yaitu layak digunakan.

a. Aspek Kelayakan Bahasa

Hasil penilaian terhadap kelayakan penuntun praktikum kimia dasar II terintegrasi PBL berdasarkan aspek kelayakan bahasa dapat dilihat pada grafik yang ada pada gambar 4.3

Hasil uji kelayakan aspek bahasa penuntun praktikum terintegrasi PBL memiliki rata-rata 3,75 yang artinya layak digunakan. Ada 3 komponen aspek bahasa yaitu (1) ketepatan struktur kalimat memiliki rata-rata 4 yaitu layak digunakan, (2) ketepatan penggunaan ejaan dan tanda baca dengan nilai rata-rata 3,5 yaitu layak digunakan, (3) ketepatan penggunaan bahasa yang komunikatif dengan nilai rata-rata 3,75 yaitu layak digunakan.

Adapun rata-rata keseluruhan dari 22 aspek yang dinilai oleh validator menunjukkan skor 3,86 yang memiliki kriteria valid, sehingga secara umum produk yang dikembangkan yaitu penuntun praktikum kimia dasar II terintegrasi PBL sudah layak digunakan.

Pada angket validasi diperoleh komentar dan saran oleh validator di mana komentar dan saran tersebut akan dijadikan bahan pertimbangan dalam merevisi penuntun praktikum kimia dasar II terintegrasi Problem Based Learning (PBL).

Tabel di bawah ini menyajikan komentar dan saran dari validator.

\section{b. Uji Coba Terbatas Penuntun Praktikum Kimia Dasar II Terintegrasi Problem Based Learning (PBL)}

Berdasarkan hasil observasi peneliti terhadap sikap (afektif) mahasiswa dan keterampilan (psikomotorik) mahasiswa Pendidikan Kimia Universitas Muhammadiyah Tapanuli Selatan (UMTS) dalam melakukan praktikum yang ada pada Penuntun praktikum 
kimia dasar II terintegrasi PBL yang telah dikembangkan peneliti menemukan bahwa pada langkah merumuskan masalah dan kesimpulan, mahasiswa masih merasa bingung dan belum mengerti apa yang akan dilakukan pada langkah tersebut. Kemudian, pada petunjuk percobaan, mahasiswa juga belum terbiasa merancang percobaan secara mandiri di mana mahasiswa sering bertanya kebenaran langkah kerja percobaan yang mereka rancang kepada peneliti selama proses praktikum.

\section{Hasil Penilaian Afektif Mahasiswa}

Pada lembar afektif terdapat 4 aspek yang dinilai yaitu (A) Mahasiswa dapat mengajukan pertanyaan, (B) mahasiswa dapat menjawab pertanyaan, (C) mahasiswa dapat mengemukakan pendapat, (D) mahasiswa mengikuti proses pembelajaran dengan tertib dan disiplin.

Hasil penilaian afektif mahasiswa dalam melakukan praktikum menggunakan penuntun praktikum kimia dasar II terintegrasi PBL yaitu sebesar 73,21 yaitu nilai afektif mahasiswa sudah baik. Mahasiswa dengan kelompoknya berusaha memecahkan masalah sehingga mereka bisa menjawab pertanyaan dari asisten laboratorium dan mengemukakan pendapat sendiri walaupun masih dimotivasi dan dimonitoring oleh asisten laboratorium sehingga mereka bisa memperoleh pengetahuan yang lebih bermakna.

\section{Hasil Penilaian Psikomotorik Mahasiswa}

Penilaian psikomotorik meliputi 2 aspek penilaian yaitu (1) Mahasiswa mampu menggunakan alat dan bahan percobaan, (2) mahasiswa mampu merangkai alat percobaan.

Hasil penilaian psikomotorik mahasiswa dalam melaksanakan praktikum kimia dasar II menggunakan penuntun praktikum kimia dasar II terintegrasi PBL memiliki ratarata sebesar 75 yaitu nilai psikomotorik mahasiswa sudah baik karena pada praktikum terintegrasi PBL mahasiswa dituntut aktif berpartisipasi melakukan praktikum dengan menyuguhkan masalah-masalah yang akan mengarahkan mereka melakukan eksperimen tersebut sehingga mereka memperoleh pengalaman dan pengetahuan baru yang lebih bertahan lama dan mudah diingat dibandingkan dengan pengetahuan yang diperoleh dengan cara lain namun masih memerlukan arahan dan bimbingan asisten laboratorium. 
Oleh karena itu, berdasarkan hasil penilaian di atas peneliti menyimpulkan bahwa mahasiswa Pendidikan Kimia dalam melaksanakan percobaan belum terlatih untuk melakukan percobaan terintegrasi PBL. Hal ini terjadi karena selama percobaan menggunakan penuntun kimia dasar II mahasiswa mengikuti semua tahapan-tahapan prosedur praktikum selalu dibantu oleh asisten laboratorium sementara dengan penuntun terintegrasi PBL mahasiswa dituntut mandiri walaupun kegiatan praktikum dilakukan secara berkelompok, karena pada penuntun praktikum terintegrasi PBL mahasiswa dihadapkan pada suatu masalah yang diharapkan mahasiswa tertarik untuk memecahkan permasalahan tersebut untuk meneliti lebih jauh sehingga menghasilkan pengetahuan baru. Pemberian tugas dan penilaian yang dilakukan tetap bersifat individual maka setiap siswa harus terlibat aktif dalam praktikum.

Berdasarkan hasil uji coba, nilai rata-rata pretes mahasiswa sebelum melakukan praktikum menggunakan Penuntun praktikum kimia dasar II sebesar 69,29 dan nilai ratarata postes mahasiswa setelah melakukan praktikum menggunakan Penuntun praktikum kimia dasar II terintegrasi PBL sebesar 83,57. Dari rata-rata pretes dan postes ini ditentukan nilai gain ternomalisasi hasil belajar pada kelas tersebut.

Adapun perhitungan gain ternormalisasi menggunakan rumus :

$$
\begin{aligned}
G & =\frac{\text { skor postest }- \text { skor pretest }}{\text { skor maksimum }- \text { skor pretest }} \\
& =\frac{83,57-69,29}{100-69,29} \\
& =\frac{14,28}{30,71} \\
& =0,46
\end{aligned}
$$

Diperoleh skor gain $(G)=0,46$ maka sesuai dengan klasifikasi uji gain dimana $0,30 \leq \mathrm{G} \leq 0,7$ klasifikasi secara signifikan berada pada kategori sedang. Berarti, efektifitas Penggunaan Penuntun praktikum kimia dasar II terintegrasi Problem Based Learning (PBL) terhadap hasil belajar berada pada kategori sedang.

Penuntun praktikum yang dikembangkan ini pasti mempunyai keunggulan dan kelemahan. Adapun keunggulan produk yang dikembangkan, yaitu: 1) penuntun praktikum yang dikembangkan telah melalui tahap validasi dan dilakukan uji terbatas serta revisi sehingga penuntun praktikum layak untuk digunakan; 2) kegiatan praktikum dibuat dengan sistematis, dimulai dengan penyajian materi pengantar, menyajikan 
permasalahan yang menjadi pemicu rasa ingin tahu mahasiswa untuk melakukan praktikum.

Kegiatan selanjutnya mengacu pada sintak Problem Based Learning yang membuat mahasiswa terbiasa melakukan kerja ilmiah sekaligus melatih kemampuan berpikir aktif mahasiswa, 3) kegiatan praktikum dalam penuntun praktikum yang dikembangkan ini melatih keterampilan mahasiswa dalam menggunakan alat dengan teliti serta melatih mahasiswa merancang percobaan sendiri dibantu dengan petunjuk praktikum yang ada pada penuntun praktikum, (4) tampilan penuntun dibuat lebih menarik dengan sedikit animasi dan warna yang sesuai untuk mahasiswa agar lebih memberi rangsangan bagi pembacanya tidak hanya warna hitam dan putih.

Kelemahan dari penuntun praktikum yang dikembangkan yaitu penuntun praktikum kimia dasar II terintegrasi PBL ini hanya layak digunakan di Universitas Muhammadiyah Tapanuli Selatan (UMTS) karena pengembangannya disesuaikan dengan silabus dan Satuan Acara Perkuliahan Mata Kuliah Praktikum Kimia Dasar II Universitas Muhammadiyah Tapanuli Selatan (UMTS), ketersediaan zat-zat kimia di laboratorium masih kurang lengkap serta kemampuan dasar mahasiswa Pendidikan Kimia UMTS yang dinilai tidak merata.

\section{Penutup}

1. Hasil analisis terhadap penuntun praktikum kimia dasar II UMTS masih perlu direvisi, oleh karena itu perlu dilakukan pengembangan pada penuntun praktikum tersebut.

2. Hasil pengembangan penuntun praktikum kimia dasar II dengan menggunakan model pembelajaran Problem Based Learning (PBL) sudah disesuaikan dengan isi silabus kimia dasar II UMTS.

3. Setelah diuji cobakan ke mahasiswa dapat dilihat hasil penilaian afektif mahasiswa dalam melakukan praktikum menggunakan penuntun praktikum kimia dasar II terintegrasi PBL yaitu sebesar 73,21 yaitu nilai afektif mahasiswa sudah baik. Sedangkan hasil penilaian psikomotorik sebesar 75 yaitu nilai psikomotorik mahasiswa sudah baik. 


\section{E. Daftar Pustaka}

Arikunto, Suharsimi.2010. Prosedur Penelitian Suatu Pendekatan Praktek. Jakarta: Rineka Cipta.

Borg and Gall.1983.Educational Research and Introduction. White Plain, N.Y.: Longman, Inc. Istarani.2011.Model Pembelajaran Inovatif. Medan: Media Persada.

Jahro,I.S.2009.Analisis Penerapan Metode Praktikum Pada Pembelajaran Ilmu Kimia di Sekolah Menengah Atas.Jurnal Pendidikan Kimia 1(4):20-26 UNIMED.

Kendler, B.S. dan Grove, P.A. 2004.ProblemBasic Learning in Biology Curriculum.The American Biology Teacher. 66(5),348-354.

Kurniati dan wahyuningrum. 2011. Pengembangan Pembelajaran Inkuiri Terbimbing di SMA/MA melaluiPenyusunan Modul Praktikum Isolasi dan Identifikasi Senyawa dalam Daun Tanaman Mint (Mentha cordifolia opiz),Prosiding Simposium Nasional Inovasi Pembelajaran dan Sains 2011.

Kushartanti, Wara BM. 2007. Pendekatan Problem Basic Learning Dalam Pembelajaran Praktek Kerja Lapangan Terapi Fisik.FIK Universitas Negeri Yogyakarta

Mangelep, Navel Octaviandy. Penelitian dan Pengembangan. (https://navelmangelep.wordpress.com/2012/04/01/penelitian-pengembangandevelopment-research/ ) diakses tanggal 24 November 2015

M. Heijne-Penninga. 2013. Influence of PBL with open-book tests on knowledge retention measured with progress tests. Adv in Health Sci Educ (2013) 18:485-495DOI 10.1007/s10459-012-9386-8

Munika, Mujamil Jejem. 2013. Pengembangan Petunujuk Praktikum Larutan Asam Basa Berbasis Inquiry.Program Studi Pendidikan Kimia FKIP Universitas Sriwijaya.

Nofiana Indah. 2013. Pengembangan Panduan Praktikum Kimia Berbasis Inquiry Terbimbing Kelas X. Prodi Pendidikan Kimia Universitas Lampung.

Rohman.M, 2013. Strategi \& Desain Pengembangan Sistem Pembelajaran. Prestasi Pustakaraya. Jakarta.

Setyosari, Punaji.2010. Metode Penelitian Pendidikan Dan Pengembangan Edisi Ketiga,PT.Fajar Interpratama Mandiri, Jakarta.

Sugiyono.2012. Metode Penelitian Kuantitatif, Kualitatif, dan $R$ \& D, Alfabeta, Bandung.

Tessa A. Nicholl. 2013. A Model for Small-Group Problem-Based Learning in a Large ClassFacilitated by One Instructor. American Journal of Pharmaceutical Education 2012; 76 (6) Article 117.

Tuysuz, C.2010. The Effect of The Virtual Laboratory on Studen's Achievement and Attitude in Chemistry.International Online Journal Educational Sciences (IOJES), 2(1): 37-53.

Wan Syafii. 2013. Problem Solving Skills and Learning Achievements Through Problem Based Module ieaching and Learning Biology in High School.Asian social Science, Vol 9, No 12; 2013.

Xue H, 2013. 3C3R Modified PBL Pediatric Teaching of Chinese Medical Students. PLoS ONE 8(5): e63412. doi:10.1371/journal.pone.0063412

Zakiah. 2015. Pengembangan Penuntun Praktikum Tipe Discovery Dan Tipe Project Based Learning Pada Pembelajaran Elektrolit Dan Non Elektrolit Di SMA.Jurnal Pendidikan Kimia, 7(1): 70-79. Program Pascasarjana, UNIME 